DOI 10.18551/rjoas.2019-02.19

\title{
THE STUDY OF EFFECT OF GOOD CORPORATE GOVERNANCE ON FINANCIAL PERFORMANCE
}

\author{
Sianipar R.H. ${ }^{*}$, Wiksuana I.G.B. \\ Faculty Economic and Business, University of Udayana, Bali, Indonesia \\ ${ }^{\star}$ E-mail: robert sianipar@ojk.go.id
}

\begin{abstract}
Increasingly rapid economic development requires all companies to be more sensitive in reading situations and conditions both viewed from the internal and external sides of the company. The survival of a company depends on its corporate governance. This study aims to prove the significance of the effect of good corporate governance on financial performance in Regional Development Banks. The population in this study is all Regional Development Banks in Indonesia, which are 26 Banks. The method in determining the sample in this study used saturated samples. The data in the study are secondary data. The data analysis technique used is Simple Linear Regression. The results of this study found that corporate governance has a positive effect on the performance of Regional Development Banks. This study can provide information to consider the application of good corporate governance to the financial performance of Regional Development Banks. Regional development banks are still able to maintain financial performance standards that have been signaled by Bank Indonesia.
\end{abstract}

\section{KEY WORDS}

Good corporate governance, bank performance, ROA.

Corporate Governance is corporate governance that explains the relationship between various parties in the company that determines the direction and performance of the company (Sutedi, 2012). The application of good corporate governance, known as good corporate governance, can help stakeholders to know the condition of the company through disclosure of accurate, timely and transparent financial performance.

The application of the concept of good corporate governance is also very important for the banking sector. The banking sector is a financial services industry that plays an important role in the development of the country's economy; moreover banks have more stringent regulations when compared to other industrial sectors. Banks must meet the minimum CAR conditions and be declared healthy by Bank Indonesia determined from their financial statements. To create a healthy, strong and trustworthy banking industry, banks must be professionally managed in terms of human resources and management. Banking deregulation in 1988 indirectly played a role in the economic crisis experienced by Indonesia in 1998. The crisis destroyed the country's economy, including the banking sector, which resulted in a decline in banking financial performance.

BPD has several problems including limited products and services, low human resources, lack of partnerships and lack of capital. In accordance with Joint Press Release No SP 43 / DKNS / OJK / 05/2015 explained that the Regional Development Banks throughout Indonesia (BPD-SI) continued to show that growth could be seen from their financial performance. In accordance with Indonesian Banking Statistics as of March 2015, BPD's total assets amounted to Rp 498,951 trillion or an increase of $22.39 \%$ compared to the position in March 2014 which reached Rp 407,669 trillion. BPD's credit performance also showed good growth, seen in March 2015, BPD's credit position reached Rp. 304,492 trillion, an increase of $13.02 \%$ compared to March 2014's position of Rp. 269,419 trillion. Third Party Funds (DPK) also increased in March 2015 by 28.15\% from Rp. 320,552 in March 2014 to Rp. 410,781 trillion.

It can be concluded that with these fundamental problems, BPD still shows an increase in financial performance growth, even though the increase has not been able to overcome 
the fundamental problems faced by BPD. So that the main goal of a company to get maximum profit has not been achieved. The application of the concept of good corporate governance in the BPD is expected to minimize risks and overcome problems with the BPD and can improve BPD performance. The main objective of the bank in its operational activities is to achieve a maximum level of profitability (Anggreni \& Suardika, 2014).

Profitability is the company's ability to generate profits through all the capabilities and resources it has (Hery, 2014: 192). Profitability is an important indicator for investors in assessing the performance of a company because it shows the company's ability to obtain profits and the rate of return that investors will receive. Profitability describes whether a business entity has good opportunities or prospects in the future. The higher the profitability of the business entity, the more the company's ability to maintain its survival will be guaranteed (Hermuningsih, 2013). The profitability ratio used in this study is Return on Assets or ROA. ROA is chosen as an indicator to measure profitability ratios because ROA is the most frequently used profitability ratio and is able to show the success of a company in generating profits on the management of assets owned by the company (Muniroh, 2014).

Research on the effect of corporate governance on financial performance has been carried out as much as Zabri's research (2015) examined the effect of corporate governance on financial performance, in this study board size and board independence were used as corporate governance indicators. Financial performance indicators in research conducted in Malaysia use return on assets (ROA) and return on equity (ROE). The use of ROA and ROE as a financial performance indicator because the ratio is believed to be a ratio that truly shows the company's performance in a given year and is a very useful ratio for stakeholders or stakeholders.

In Indonesia, Arifani (2013) examined the effect of corporate governance on financial performance by using the variable number of audit committees, proportion of managerial ownership, proportion of institutional ownership, proportion of board of commissioners, and ROE. The results of this study indicate that there is an influence between the audit committee, institutional ownership, and independent commissioners on financial performance. Whereas in this study it was not found that managerial ownership has an influence on financial performance. Laksana (2015) also examined the effect of corporate governance on financial performance. The Laksana Research (2015) is almost the same as the research conducted by Arifani (2013) that differentiates is an indicator for financial performance where Laksana (2015) uses ROA for financial performance indicators.

\section{LITERATURE REVIEW}

Based on agency theory explains the relationship between Good Corporate Governance (GCG) and profitability. This can be seen if the good corporate governance, the company can run its business efficiently, so that it can achieve the company's goals, namely maximum profit. Good governance can occur if the agent can manage the company properly according to what has been set by the regulator, so that it can increase the profitability of the company which is the main goal of the company and the principal.

GCG assessment aims to assess the adequacy of bank governance structure and infrastructure so that the process of implementing GCG principles can produce results that are in line with the expectations of bank stakeholders (Tjondro \& Wilopo, 2011). The implementation of good corporate governance based on five basic principles in accordance with BI BI No. 15/15 / DPNP, namely openness, accountability, accountability, indpendency and fairness, is expected to provide a positive relationship to bank profitability. This can be caused, because the high value of profitability of a bank will reflect good corporate governance, and vice versa if the value of low profitability can be caused by the lack of good corporate governance (Suciati, 2015).

This statement is supported by the results of research conducted by Ajanthan (2013), Tjondro \& Wilopo (2011), and Zabri (2015) Good Corporate Governance (GCG) has a significant positive effect on return on assets (ROA). Based on this hypothesis in this study are: 


\section{$\mathrm{H}_{1}$ : Good Corporate Governance Has a Positive and Significant Effect on Financial Performance.}

\section{METHODS OF RESEARCH}

This research was conducted on the performance of 26 Regional Development Banks in Indonesia while the object of this research was reports on good corporate governance and bank performance (annual financial reports) in the period 2014 to 2016 . The samples in this study were all BPDs in Indonesia, namely 26 BPDs. The method of data collection in this study is a non-behavioral observation method that is data collection by observing, recording, and studying the descriptions of journals, books and documents. In this study, data collection is done by observing, recording and studying scientific works in the form of journals, theses, books and documents in the form of reports on the implementation of good corporate governance and annual reports, which are obtained from the websites of each bank.

\section{RESULTS AND DISCUSSION}

Table 1 - T-Test Result

\begin{tabular}{|c|c|c|c|c|c|c|}
\hline & \multirow{2}{*}{ Model } & \multicolumn{2}{|c|}{ Unstandardized Coefficients } & \multirow{2}{*}{$\begin{array}{c}\text { Standardized Coefficients } \\
\text { Beta }\end{array}$} & \multirow[b]{2}{*}{$t$} & \multirow{2}{*}{ Sig. } \\
\hline & & B & Std. Error & & & \\
\hline 1 & $\begin{array}{l}\text { (Constant) } \\
\text { GCG }\end{array}$ & $\begin{array}{l}, 027 \\
, 000 \\
\end{array}$ & $\begin{array}{l}, 001 \\
, 000 \\
\end{array}$ & 309, & $\begin{array}{c}23,474 \\
2,829 \\
\end{array}$ & $\begin{array}{l}, 000 \\
, 006 \\
\end{array}$ \\
\hline
\end{tabular}

Source: Primary Data, 2018.

Based on the above table obtained sig value of 0.006 which is smaller than 0.05 with a regression coefficient of 0.000 . This shows that the research hypothesis which states corporate governance has a positive effect on the performance of the BPD is accepted.

This study found that good corporate governance has a significant positive effect on financial performance. The implementation of good corporate governance in regional Development Banks in Indonesia is measured by GCG Self Assessment in accordance with Bank Indonesia Regulation Number 13/1 / PBI / 2011. The implementation of good corporate governance can make the management of the company more focused and clear in the division of tasks and authority and supervision. The right application of good corporate governance is the main capital of the company to gain the trust of customers, investors, prospective investors and stakeholders so as to enable the company to implement good corporate governance with high standards with business objectives and business growth, profitability, added value and increasing capability for sustainability company life can be achieved well. Return on Assets is used to evaluate whether management has received a reasonable return from the assets it controls. This ratio is the best measure if someone wants to evaluate how well the company has used the funds. Therefore, Return on Assets are often used by top management to evaluate business units within a company.

The findings of this study indicate that the implementation of GCG in Financial Institutions is very important in order to improve its financial performance. Sutedi (2012: 2-3), said that good corporate governance is a system that regulates and controls companies to create added value. The application of the principles of good corporate governance can consistently improve the quality of financial statements and hinder performance engineering activities that result in financial statements not describing the company's fundamental values.

The application of good corporate governance can make the management of the company more focused and clear in the division of duties and responsibilities and supervision. The right application of good corporate governance is the company's main capital to gain the trust of customers, investors, prospective investors and stakeholders so as to enable companies to implement good corporate governance with high standards with business objectives and business growth, profitability, added value and increased ability to sustain company life can be achieved well. If the company implements good corporate governance, then the corporate governance will be good. Good corporate governance makes 
the company capable of carrying out its operational activities well so that the company produces good financial performance. The results of this statistical test are also supported by previous research. Research A. Ajanthan (2013), Tjondro \& Wilopo (2011), and Zabri (2015) Good Corporate Governance (GCG) has a significant positive effect on return on assets (ROA).

\section{CONCLUSION}

Based on the above research it can be concluded that corporate governance has a positive effect on BPD performance. With the implementation of good corporate governance as measured by Bank Indonesia Regulation Number 13/1 / PBI / 2011, it is able to improve BPD performance in Indonesia as measured by profitability.

\section{REFERENCES}

1. Ajanthan. (2013). Impact of Corporate Governance Practices on Firm Capital Structure and Profitability: A Study of Selected Hotels and Restaurant Companies in Sri Lanka. Journal of Finance and Accounting, 4(10), Hal. 1-13.

2. Alamsyah, Halim, 2012. Kinerja Bank Pembangunan Daerah di Indonesia: Kontribusi untuk Pembangunan Daerah. Sambutan pada Seminar Nasional Kinerja Bank Pembangunan Daerah di Indonesia.

3. Anggreni, Made Ria., Suardhika, I Made Sadha. (2014). Pengaruh Dana Pihak Ketiga, Kecukupan Modal, Risiko Kredit and Suku Bunga Kredit pada Profitabilitas. E-Jurnal Akuntansi Universitas Udayana. 9(1), Hal. 27-38.

4. Arifani, Rizky. 2013. Pengaruh Good Corporate Governance Terhadap Kinerja Keuangan Perusahaan (Studi Pada Perusahaan yang Tercatat Di Bursa Efek Indonesia). Skripsi. Malang: Universitas Brawijaya.

5. Bathala, C.T., et. Al, 1994, Managerial Ownership, debt policy, and the impact of institutional holdings; and agency perspective. Financial Management 23, pp. 38-50.

6. Besari, 2009. Pengaruh Kualitas Pelaksanaan GCG, Ukuran and Kompleksitas Bank Terhadap Fraud, Tesis, Program Pascasarjana, Universitas Diponegoro.

7. Brigham, E.F., Gapenski L.C. and Daves P.R., 1999, Intermediate Financial Management, Sixth Edition, the Dryden press, Harcourt Brace College Publishers.

8. Eka, 2011. Pengaruh Penerapan Corporate Governance Terhadap Kinerja Keuangan Pada Industri Perbankan Yang Terdaftar di BEI tahun 2006-2008, Fakultas Ekonomi, Universitas Diponegoro.

9. El-Chaarani, H. (2014). The Impact of Corporate Governance on the Performance of Lebanese Banks. The International Journal of Business and Finance Research, 8(5), 2234. FCGI. (n.d.).p

10. Elizabeth Webb, (2008),"Bank stock repurchases extent and measures of corporate governance", International Journal of Managerial Finance, Vol. 4 Iss: 3 pp. 180 - 199.

11. Ghozali, Imam, 2016. Aplikasi Analisis Multivariat dengan Program IBM SPSS 21, Semarang, Badan Penerbit Universitas Diponegoro.

12. Haryono, Slamet, 2005. Struktur Kepemilikan Dalam Bingkai Teori Keagenan. Jurnal Akuntansi and Bisnis, Vol.5, No.1.

13. Hassan Al-Tamimi, Hassan, 2012. The Effects of Corporate Governance on Performance and Financial Distress: The Experience of UAE National Banks. Journal of Financial Regulation and Compliance, Vol. 20 Iss: 2 pp. $3-3$.

14. Hastuti, Yenny Widya and Achmad, Tarmizi (2011). Pengaruh mekanisme Corporate Governance secara Internal and Eksternal terhadap kinerja keuagan: studi kasus di 20 Bank yang terdaftar di BEI 2006-2009", Undergraduate thesis, Universitas Diponegoro.

15. Hery. (2014). Analisis Kinerja Manajemen: The Best Financial Analysis, Menilai Menilai Kinerja Manajemen Berdasrkan Rasio Keuangan. Jakarta: PT. Grasindo. 
16. Hermuningsih, Sri. 2013. Pengaruh Profitabilitas, Growth Opportunity, Struktur Modal terhadap Nilai Perusahaan pada Perusahaan Publik di Indonesia. Buletin Ekonomi Moneter and Perbankan.

17. Jatiningrum C. and Rofiqoh I, 2004, Struktur Kepemilikan and Manajemen Laba, paper unpublished, Simposium Dwi Tahunan the Center for Accounting and Management Development, Universitas Teknologi Yogyakarta.

18. Jensen, M and W. Meckling. 1976., "Theory of the firm; managerial behaviour, agency costs and ownership structure". Journal of Financial Economics 3, pp. 305-360.

19. Jumandani, Romi. 2012. Pengaruh Penerapan Good Corporste Governance Terhadap Kinerjs Keuangan. Skripsi Sarjana Akuntansi pada Universitas Lampung. Lampung.

20. Laksana, jaya. 2015. Corporate Governance and Kinerja Keuangan (Studi Pada Perusahaan Perbankan yang Terdaftar Di BEI Periode 2008-2012). E-Jurnal Akuntansi Universitas Udayana 11.12015.

21. Macey and O'Hara, 2003. The Corporate Governance of Banks. Economic Policy Review.

22. Margaritis and Psillaki, 2010. Capital structure, equity ownership and firm performance. Journal of Banking \& Finance, Vol.34 pp. 621-632

23. Mehran, Hamid, 2003. Corporate Governance In the banking and financial services industries. Journal of Financial Intermediation, Vol.13.

24. Muniroh, D. M. (2014). Analisis Kinerja Keuangan menggunakan Metode RGEC (Risk, GCG, Earning, Capital) pada Sektor Keuangan Perbankan. Jurnal Ilmu Manajemen, 2(2), Hal.1-16.

25. Nurkhin, Ahmad, 2009. Corporate Governance and Profitabilitas; Pengaruhnya Terhadap Pengungkapan Tanggung Jawab Sosial Perusahaan, Tesis, Program Pascasarjana, Universitas Diponegoro.

26. Otoritas Jasa Keuangan. (26 Mei 2015). Siaran Pers No. SP 43/DKNS/OJK/05/2015. Presiden Joko Widodo Resmikan Program Transformasi BPD Menuju Bank yang Kompetitif, Kuat and Kontributif bagi Pembangunan Daerah

27. Suciati, N. (2015). Analisis Pengaruh Risk Based Bank Rating (RBBR) terhadap Kinerja Keuangan Perbankan (studi pada Bank Umum yang terdaftar di Bursa Efek Indonesia periode 2010-2014). Jurnal Manajemen, hal.1-18.

28. Sudarma, Made, 2003, Pengaruh Struktur Kepemilikan Saham, Faktor Intern, Faktor Ekstern terhadap Struktur Modal and Nilai Perusahaan, Desertasi Program Pascasarjana Universitas Brawijaya Malang.

29. Sujoko and Soebiantoro, 2007. Pengaruh Struktur Kepemilikan Saham, Leverage, Faktor Intern and Faktor Ekstern Terhadap Nilai Perusahaan, Jurnal Ekonomi Manajemen, Vol.9 No.1, Fakultas Ekonomi, Universitas Kristen Petra.

30. Sutedi, Andrian. 2012. Good Corporate Governance. Jakarta: Sinar Grafika

31. Tjondro, D., \& Wilopo, R. (2011). Pengaruh Good Corporate Governance (GCG) terhadap Profitabilitas and Kinerja Saham Perusahaan Perbankan yang Tercatat di Bursa Efek Indonesia. Journal of Business and Banking, 1(1), Hal.1-14.

32. Undang-undang No.10 tahun 1998 tentang Perbankan.

33. Undang-undang No.8 tahun 1995 tentang Pasar Modal.

34. Zabri, Shafie Mohamed \& Ahmad, Kamila. 2015. Corporate Governance Practices and Firm Performance: Evidence from Top 100 Public Listed Companies in Malaysia. Procedia Economics and Finance 35 (2016) 287 - 296. 